\title{
Effect of international collaboration on knowledge flow within an innovation system: a Triple Helix approach
}

Eustache Mêgnigbêto ${ }^{1,2}$

\section{Correspondence:} eustachem@gmail.com

${ }^{1}$ Bureau d'études et de recherches en science de l'information, 09 BP 477 Saint Michel, Cotonou, Benin

${ }^{2}$ Institute for Education and Information Sciences, IBW University of Antwerp, Venusstraat 35, B-2000 Antwerp, Belgium 
French: Les effets de la collaboration internationale sur le flux des connaissances au sein d'un système d'innovation: une approche de type Triple Hélice

Résumé: Les articles de recherche qui se sont intéressés à la Triple Hélice en relation avec les publications internationales à signatures multiples envisagent la collaboration internationale comme le quatrième élément du système. L'article considère trois niveaux d'étude pour rendre compte de l'effet de la collaboration internationale sur un système d'innovation :le niveau interne, externe, et global. L'information mutuelle et la puissance de la transmission sont utilisées comme indicateurs. Des données bibliographiques sur la Corée du Sud et l'Afrique de l'Ouest sur une période de dix ans (2001-2010) ont été téléchargées et importées vers une application bibliographique. On a recensé les acteurs de la Triple Hélice et leurs contributions de collaboration bi- ou trilatérale par zone considérée, année et niveau de collaboration. Puis, on a calculé l'information mutuelle et la puissance de transmission. Les résultats montrent qu'au niveau interne le système d'innovation de la Corée du Sud est plus intégré que celui de ses partenaires, à l'inverse de celui d'Afrique de l'Ouest qui l'est moins. Les résultats montrent aussi que la collaboration internationale renforce le partage des connaissances au niveau interne dans les deux régions mais dans une mesure différente; en d'autres termes les deux régions ont profité de la collaboration internationale en termes de flot de connaissances.

Spanish: El efecto de la colaboración internacional en el flujo del conocimiento dentro de un sistema de innovación: La perspectiva de la Triple Hélice

Resumen: La literatura de la Triple Hélice en relación a la co-autoría considera que la colaboración internacional es un cuarto elemento del sistema. En este trabajo se sugiere considerar tres niveles de estudio para evaluar el efecto de la colaboración internacional en un sistema de innovación: el nacional, el exterior y el global. La "información mutua" y la "potencia de transmisión" se utilizan como indicadores. Datos bibliográficos de Corea del Sur y de la región de África Occidental por el período de diez años entre 2001 y 2010 fueron descargados e importados a una aplicación de software bibliográfico. Las búsquedas ejecutadas establecieron el carácter de la contribución (bi o trilateral) de los actores de la Triple Hélice según área, año, y nivel. Luego, la información mutua y la potencia de transmisión fueron calculadas. Los resultados muestran que en el ámbito interno, el sistema de innovación de Corea del Sur está más integrado que el África Occidental. El contraste es aún más claro con respecto de los socios internacionales de ambas regiones. No obstante de ello, los resultados muestran que la colaboración internacional ha fortalecido el intercambio de conocimientos a nivel nacional, tanto para Corea del Sur como para África Occidental; en otras palabras, las dos áreas se han beneficiado de la colaboración internacional en términos de flujo de conocimiento.

Chinese: 在西非技术创新体系内的信息流

摘 要:: 我们把交互信息和传输功率用作在创新主体之间的知识循环的指标。在 科学出版物中的分析单位用至少一个基于西非的地址在科学网上进行索引收 录。我们发现，在区域的层次上，大学是最大的知识生产者，其次是政府,最后是产 业; 然而,在国家的层面上,在大多数国家里政府是最大的信息生产者。无论在区 域还是在国家层面上,产业部门的输出都很弱。在一些国家它甚至等于零。交 互信息表明,在区域和国家层面上都有(三螺旋)三个创新主体之间的协同作用的 存在。然而, 这种作用的值太低, 以至于不能让知识畅快地在主体之间循环。 
Russian: Влияние международного сотрудничества на движение знаний в инновационной системе: трехспиральный подход

Аннотация: В исследованиях, в которых рассматривается Тройная спираль в связи с интернациональным соавторством, международное сотрудничество выделяется в качестве четвертого элемента системы. В настоящей работе предлагается изучение эффектов от международного сотрудничества на трех уровнях: национальном, зарубежном и глобальном. В качестве показателей были использованы взаимное информирование и мощность передачи. Авторами систематизированы публикации в Южной Корее и Западно-Африканском регионе за 10-летний период (2001-2010) и исследованы в специализированном программном приложении для проведения библиографического анализа. Поиск проводился с целью выявления участников Тройной спирали и их двух- или трехстороннего сотрудничества в рассматриваемых секторах, годах и уровнях. Затем были рассчитаны взаимное информирование и мощность передачи. Результаты показали, что на национальном уровне Южнокорейская инновационная система является более интегрированной, в то время как Западно-Африканский регион демонстрируется меньшую вовлеченность по сравнению со своими партнерами. Также полученные данные позволили сделать вывод, что международное сотрудничество способствует интенсификации обмена знаний на национальном уровне как в Южной Корее, так и Западной Африке, но в разной степени; другими словами, два региона получают преимущества от международного сотрудничества в контексте движения знаний.

Portuguese: $O$ efeito da colaboração internacional no fluxo de conhecimento dentro do sistema de inovação: uma abordagem de Hélice Tríplice

Resumo: Artigos de pesquisa que estudaram a hélice tríplice em relação com a co-autoria internacional consideraram a colaboração internacional como o quarto elemento do sistema. Esse artigo sugere considerar três níveis de estudo para avaliar o efeito da colaboração internacional em um sistema de inovação: o doméstico, o estrangeiro e o global. A informação mútua e o poder de transmissão foram utilizadas como indicadores. Dados bibliográficos da Coréia do Sul e da região da África Ocidental foram extraídos por um período de 10 anos (2001-2010) e importados para uma aplicação de software bibliográfico. Pesquisas foram realizadas para determinar os atores da Hélice Tríplice e suas contribuições de colaborações bi ou trilaterais por área considerada, ano e nível. Em seguida, a informação mútua e o poder de transmissão foram computados. Resultados mostram que, a um nível interno, o sistema de inovação Sul Coreano é mais integrado, enquanto que o da África Ocidental é menos integrado do que o de seus parceiros. Resultados mostraram também que a colaboração internacional tem reforçado o compartilhamento de conhecimento a nível nacional tanto para Coréia do Sul e África Ocidental, mas com diferenças de extensão; em outras palavras, as duas áreas se beneficiaram da colaboração em termos de fluxo de conhecimento.

\section{Multilingual abstract}

Please see Additional file 1 for translation of the abstract into Arabic.

\section{Introduction}

Two types of models of innovation were proposed up to now to explain the functioning of an economy: the linear and the nonlinear models. Each explains how growth is 
generated. The linear model postulated that 'innovation starts with basic research, is followed by applied research and development, and ends with production and diffusion' (Godin 2005; Godin 2006; Godin 2014). The nonlinear model introduced with the national innovation system concept 'suggests that the research system's ultimate goal is innovation and that the system is a part of a larger system composed of sectors like government, university and industry and their environment. The system also emphasized the relations between the components or sectors as the "cause" explaining the performance of innovation systems' (Godin 2007). Both models have been criticised (Godin 2005; Godin 2006; Godin 2007) and variants of them were proposed. In the national innovation system model, analysis focuses on the flows of knowledge between actors (OECD 1997).

The Triple Helix laid down by Etzkowitz and Leydesdorff (1995) and Etzkowitz and Leydesdorff (2000) is one of the variants of the nonlinear model of innovation (cf. Etzkowitz and Leydesdorff 2000; Leydesdorff 2012; Meyer et al. 2014). The model postulates that the interactions between university, industry and government maintain a knowledge infrastructure that generates knowledge of which circulation among innovation actors drives economic growth and social welfare (Leydesdorff and Etzkowitz 2001). The mutual information (Leydesdorff 2003) was elaborated as an indicator of the Triple Helix relationships between university, industry and government. It has been used widely to assess countries or region profiles (e.g. Leydesdorff and Sun 2009; Khan and Park 2011; Shin et al. 2012; Leydesdorff et al. 2013a; Mêgnigbêto 2013a; Mêgnigbêto 2015a; Mêgnigbêto 2015b) or assess the knowledge base of economies (e.g. Park et al. 2005; Park et al. 2005; Leydesdorff and Zhou 2013; Leydesdorff et al. 2015). The transmission power was proposed by Mêgnigbêto (2014a) as the normalisation of the mutual information. It was used to assess the knowledge flow within the West African innovation systems, both at national and regional levels (Mêgnigbêto 2014b; Mêgnigbêto 2014c); it was also used to compare the knowledge production profiles of six OECD countries (Mêgnigbêto 2015a; Mêgnigbêto 2015b). Jointly with other indicators, it helped in studying the Norwegian innovation system both at national and county levels, based on data including the number of establishments in geographical, organisational and technological dimensions over a 13-year period (Ivanova et al. 2014).

The Triple Helix model lays on collaboration. When publications serve as unit of analysis, co-authorship is taken as a measurement of collaboration (Katz and Martin 1997; Bordons and Gomez 2000; Olmeda-Gómez et al. 2008; Abbassi et al. 2012); indeed, it entails the tacit transfer of information and knowledge (Olmeda-Gómez et al. 2008) and ensures diffusion of ideas and knowledge circulation (Guns and Rousseau 2014). The importance of co-authorship in knowledge creation and sharing may be measured by the international co-authorship trend. Indeed, publications on coauthorship worldwide all reported an increasing trend in the number of authors who contributed to an article (e.g. Bordons and Gomez 2000; Tijssen 2007; Leydesdorff and Wagner 2008; Boshoff 2009; Adams et al. 2010a; Onyancha and Maluleka 2011; Toivanen and Ponomariov 2011; Adams 2012; Leydesdorff et al. 2013b; Mêgnigbêto 2013b; Adams et al. 2014; Ossenblok et al. 2014). Some of them underlined the concentration of the growth in the group of papers with five or more authors, lending strong importance to collaboration. As an illustration, research collaboration networks have been evolving and countries that were at the periphery are becoming a member of the core; 
besides, the global international collaboration network had become denser (Leydesdorff and Wagner 2008). Globally, co-authorship has exploded recently (Adams 2012) and internationalisation of collaboration characterises science today (Adams 2013) due mainly to globalisation. Therefore, by means of collaboration, innovation actors contributed to synergy and knowledge creation at both national and international levels. Leydesdorff and Zawdie (2010) affirmed that 'knowledge-based economy develops as a dynamic system at the global level, thus transcending national or geographical boundaries'.

At our knowledge, few papers studied international co-authorship in relation to the Triple Helix. Firstly, Leydesdorff and Sun (2009), Kwon (2011) and Kwon et al. (2012) included the internationally co-authored papers as the fourth element of the model; this method requires a huge amount of data processing and cleaning of the institutional address information (Leydesdorff and Sun 2009). Secondly, Choi et al. (2015) studied the intra-sector co-authorship at the international level. And thirdly, Shin et al. (2012) combined domestic and international collaboration by university, industry and government and their bi- or trilateral output. The abovementioned studies computed neither the synergy or knowledge the national innovation actors contributed abroad nor its effect on the synergy or knowledge creation and sharing at national level; therefore, they could not measure the real amount of knowledge that circulates among an areas' innovation actors (Mêgnigbêto 2015a; Mêgnigbêto 2015b). Indeed, globalisation has given opportunities to researchers to collaborate worldwide regardless the distance. Besides, it has eroded some countries' mutual information (Leydesdorff and Sun 2009; Kwon et al. 2012; Leydesdorff and Park 2014), and should have affected how knowledge is shared at the country level.

Because the mutual information at a country's level could have been eroded by international co-authorship, it is not sufficient alone to indicate how knowledge-based an economy is (Mêgnigbêto 2015a; Mêgnigbêto 2015b). So, while comparing countries on the basis of the mutual information or derived indicators, the effect of international collaboration remains unilluminated. Thus, the comparison may be biassed. As an example, the Japanese research performance is driven by domestic activity (Adams et al. 2010b); this country's mutual information was always higher compared with that of other countries (Leydesdorff 2003; Park et al. 2005; Ye et al. 2013; Mêgnigbêto 2014a; Mêgnigbêto 2015a; Mêgnigbêto 2015b). The conclusion that the synergy at the Japanese national level is higher than elsewhere is true, but deriving that the Japanese economy is more knowledge-based than that of another country may not be.

In this paper, we hypothesise that the synergy or knowledge contributed at the international level by a country's domestic innovation actors may have affected the synergy or knowledge they created at the national level. In other words, foreign innovation actors can influence the synergy and knowledge creation and sharing at a country's level. Our research question is twofold. (1) How is the synergy or knowledge contributed abroad by an area's innovation actors due to their relations with their foreign partners measured? (2) What is the effect of international collaboration on knowledge flow within an innovation system?

\section{Methods}

The mutual information is borrowed from Shannon's (1948) information theory. Central to this theory is the notion of entropy defined as the average quantity of 
information contained in a variable. The transmission power is derived from the mutual information. Appendix 1 gives the mathematical relations between entropy, mutual information and transmission power.

\section{Domestic, foreign and global systems}

Leydesdorff and Sun (2009), Kwon (2011) and Kwon et al. (2012) named 'foreign' institutions from partner countries and considered it as the fourth element of the innovation system composed of the three national actors that are university $(\mathrm{u})$, industry (i) and government (g), leading to the computation of the mutual information $\left(T_{\text {uigf }}\right)$ of the Quadruple Helix. The type of the institutions involved is not taken into account (Fig. 1a). Our method suggests considering three levels of analysis: (1) the domestic one grouping the country- or area-based innovation actors as done in the literature hitherto, (2) the foreign one grouping the innovation actors from the partner countries, and (3) the global one grouping the two previously defined systems. Hence, the global system may be considered as composed of the 'domestic' and foreign subsystems, each with three innovation actors leading to six actors at the global level (Fig. 1b). The two sub-systems interact and exert on each other a mutual influence that may act on the synergy within each other by the mutual relationships they entertain. The relationships existing between the actors on Fig. 1a (as represented by arrows) also exist within the domestic sub-system on the one hand and the foreign one on the other hand (Fig. 1b). Abstraction is done of these relationships on Fig. 1b, however. Studying such a Sextuple Helix (Leydesdorff 2012) requires the computation of $2^{6}=64$ sectors data. ${ }^{1}$ A simpler way to proceed consists in considering the global system as if actors were from the same geographical area and studying separately the three domestic, foreign and global Triple Helix systems. Thus, one can compute the mutual information and transmission power of the domestic, foreign and the global systems using the formulas given above. We suggest using the normalised difference between the global and domestic transmission power as the effect of international collaboration on knowledge flow within an innovation system.

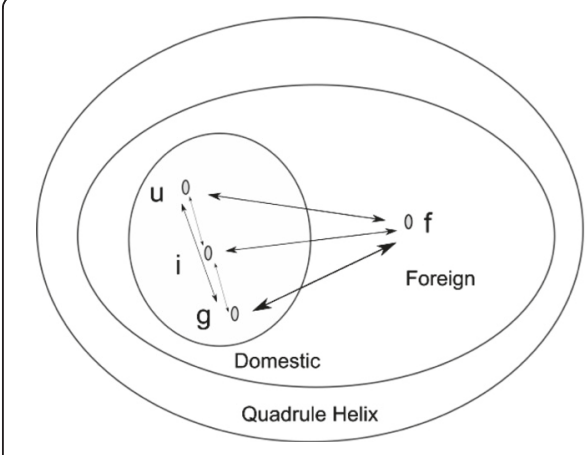

(a) Method used by Leydesdorff and Sun (2009), Kwon (2011) and Kwon et al. (2012)

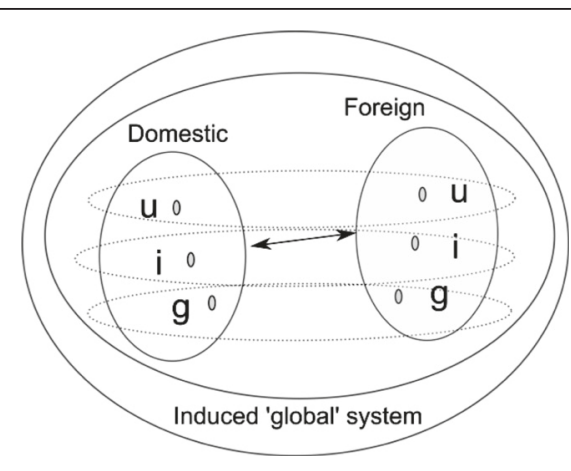

(b) Method proposed in this study

Fig. 1 Illustration of the method used by Leydesdorff and Sun (2009), Kwon (2011) and Kwon et al. (2012) (a) and the one proposed by this study (b) for integrating the international co-authorship in the Triple Helix relations. Sectors are represented by small circles meaning the intra-sectorial relations (loops) 
International collaboration and transmission power

Because a record could have both foreign and domestic co-authors, the method of entropy decomposition suggested by Theil (1972) is not applicable; indeed, the number of records from 'domestic' and that from foreign do not sum up to the number of records at the global level. We suggest computing the mutual information and transmission power of the domestic, foreign and the global systems using the formulas given above. Hence, the method (Shin et al. 2012) used computed the domestic and global mutual informations for Saudi Arabia. If we denote $\tau_{\mathrm{d}}$ the domestic transmission power, $\tau_{\mathrm{f}}$ the foreign one and $\tau_{\mathrm{g}}$ the global one, the effect of the international collaboration on an area may be measured with the scalar $\frac{\tau_{\mathrm{g}}-\tau_{\mathrm{d}}}{\tau_{\mathrm{g}}}$ expressed as percentage. We argue that the total synergy within such a system is measured by $\tau_{\mathrm{g}}$. Therefore, one can compute the total transmission power for such a country and compare countries on this basis. In this section, we do not consider the synergy created at the foreign level solely, because it does not add any value to our interpretation; furthermore, its effects combined with that of the domestic synergy are already included into the global values.

\section{Data collection}

The data source is the Web of Science. Our research question requires the distinction between the papers originated from a geographic area's university, industry and government relationships and those resulting from the collaboration with at least one university, industry or government abroad. If we could search for the first category with the Web of Science's search function, we could not for the second category. Therefore, we opted for data downloading for further relevant treatment. The primary area for the application is the West African region²; however, Korea, a country which some decades ago has the same economic and social conditions as the West African countries, has been steadily studied with regard to Triple Helix dynamics (e.g. Park et al. 2005; Park and Leydesdorff 2010; Khan and Park 2011; Kwon et al. 2012; Mêgnigbêto 2015a; Mêgnigbêto 2015b); therefore, it is chosen for comparison purpose. So, this article treats the scientific data of the West African region and South Korea. West African ${ }^{3}$ and South Korean ${ }^{4}$ publication data from Web of Science ${ }^{5}$ over a 10 -year period (2001-2010) were downloaded. The records resulting from these two searches were imported into two different bibliographic databases ${ }^{6}$ managed with CDS/ISIS $^{7}$ thanks to a programme coded into CDS/ISIS Pascal ${ }^{8}$.

\section{Data treatment}

Based on the method of Leydesdorff (2003) and Park et al. (2005) for address assignment, a list of words or abbreviations was established to attribute each record address a label: UNIV for university, INDU for industry or GOV for government. A second CDS/ISIS Pascal programme was coded for this task. A record may contain many addresses; therefore, one record may have two or more different labels. The CDS/ISIS Pascal programmes were also instructed to read the countries' name from the addresses and automatically add the associated area name: West Africa for the West African database and Korea for the South Korean database. Addresses that do not relate to any West African country or South Korea are labelled 'FOREIGN'. So, in 
the inverted file of the databases, a university in West Africa appears under the label UNIV-WEST-AFRICA, an enterprise in South Korea appears under the label INDUSOUTH KOREA and a foreign university (from the West Africa or South Korean point of view) under UNIV-FOREIGN, etc. As a result, the inverted file contains only the following keywords, in alphabetical order: ${ }^{9}$ GOV-FOREIGN, GOV-SOUTH KOREA, INDU-FOREIGN, INDU-SOUTH KOREA, UNIV-FOREIGN and UNIV-SOUTH KOREA for the South Korean data and GOV-FOREIGN, GOV-WEST-AFRICA, INDU-FOREIGN, INDU-WEST-AFRICA, UNIV-FOREIGN and UNIV-WEST-AFRICA for the West African data.

The CDS/ISIS search functions were used to compute the university, industry and government output and their bi or trilateral collaboration data at the three levels (Cf. Appendix 2). The print service of CDS/ISIS was used to output the publication year of the search results into text files for statistical analyses with the $\mathrm{R}$ software ( $\mathrm{R}$ Development Core Team 2014); then, the repartition of records per year of publication was obtained. We coded a PHP programme that computes the sectorial entropies, the bilateral entropies and mutual informations, and the trilateral entropies and mutual information and the transmission powers according to the formulas given above. All the levels of analysis (domestic, foreign and global) were taken into account.

\section{Result}

\section{Output and international collaboration}

Table 1 provides basic data on the two areas' scientific publishing over the considered periods of time: output, number of co-authors, average number of co-authors per paper, number and percentage of papers resulting from international collaboration. Over the decade, South Korea outputs a total of 368,729 papers and West Africa 30,717 papers; this leads to an annual average of 38,873 publications for South Korea and 3072 publications for West Africa. One South Korean publication out of five has at least one foreign co-author and about one half of West African publications has at least one foreign co-author. For both areas, the number of papers with at least one foreign address is increasing in absolute value; however, the trend seems to decrease very slowly in percentage. The number of co-authors per paper rose progressively from 2.39 in 2001 to 3.02 in 2010 in the case of West Africa and from 2.09 in 2001 to 2.65 in 2010 in the case of South Korea (Table 2).

Table 1 Total annual output and international collaboration data in the scientific publishing in

\begin{tabular}{llllllllllll}
\multicolumn{2}{l}{ South Korea } & $(2001-2010)$ \\
\hline Indicator & 2001 & 2002 & 2003 & 2004 & 2005 & 2006 & 2007 & 2008 & 2009 & 2010 & Total \\
\hline Annual output & 20,512 & 22,369 & 25,559 & 30,283 & 34,661 & 38,817 & 45,740 & 47,854 & 50,677 & 52,257 & 368,729 \\
$\begin{array}{l}\text { (Co-) authors } \\
42,958\end{array}$ & 51,462 & 59,090 & 69,485 & 83,158 & 92,318 & 107,731 & 113,332 & 129,140 & 138,592 & 887,266 \\
$\begin{array}{l}\text { Authors per } \\
\text { paper }\end{array}$ & 2.09 & 2.30 & 2.31 & 2.29 & 2.40 & 2.38 & 2.36 & 2.37 & 2.55 & 2.65 & 2.41 \\
$\begin{array}{l}\text { International } \\
\text { coll. }\end{array}$ & 3918 & 4705 & 5933 & 6334 & 7271 & 8005 & 8857 & 9685 & 11,142 & 12,243 & 78,093 \\
$\begin{array}{l}\text { International } \\
\text { coll. (\%) }\end{array}$ & 19.10 & 21.03 & 23.21 & 20.92 & 20.98 & 20.62 & 19.36 & 20.24 & 21.15 & 23.43 & 20.98 \\
\hline
\end{tabular}


Table 2 Total annual output and international collaboration data in the scientific publishing in West Africa (2001-2010)

\begin{tabular}{llllllllllll}
\hline Indicator & 2001 & 2002 & 2003 & 2004 & 2005 & 2006 & 2007 & 2008 & 2009 & 2010 & Total \\
\hline Annual output & 1646 & 1796 & 1945 & 2097 & 2779 & 2835 & 3642 & 4198 & 4735 & 5044 & 30,717 \\
(Co-)authors & 3932 & 4372 & 4998 & 5588 & 7233 & 7927 & 9916 & 11,745 & 13,080 & 15,215 & 84,006 \\
Authors per paper & 2.39 & 2.43 & 2.57 & 2.66 & 2.60 & 2.80 & 2.72 & 2.80 & 2.76 & 3.02 & 2.74 \\
International coll. & 863 & 927 & 1045 & 1123 & 1421 & 1464 & 1655 & 1849 & 2108 & 2386 & 14,814 \\
International coll. (\%) & 50.79 & 51.61 & 53.73 & 53.55 & 51.13 & 51.64 & 45.44 & 44.04 & 44.52 & 47.30 & 48.23 \\
\hline
\end{tabular}

\section{Triple Helix sectorial outputs}

The university (U), industry (I) and government (G) and their bi or trilateral collaboration (UI, UG, IG and UIG) outputs with regard to the level of production (e.g. domestic (d), foreign (f) and global (g)) are presented in Tables 3 and 4 for South Korea and Table 5 for West Africa. These tables illustrate the problematic of the study: for example, the line labelled 2001 in Table 5 indicates that for the West African region, U produces 829 publications at the domestic level, 376 publications at the foreign level and 816 publications at the global one. A closer analysis reveals that $829-816=13$ publications attributed to $U$ at the domestic level no longer belong to this sector at the global level. In fact, they were co-authored with other innovation actors (I or G) from foreign; so, they accounted for the collaboration of U (UI, UG or UIG) at the global level. For both areas, whatever the sectorial output is, the domestic value is higher than the global one for the Triple Helix actors but lower for their bi- or trilateral combinations.

\section{Mutual information and transmission power time series}

The mutual information and the transmission power are presented in Table 6 for West Africa and Table 7 for South Korea. They are related to the domestic, foreign and global levels. The mutual information values reveal that there is synergy within the considered innovation systems over the period of study at all levels. For the two areas under consideration, the curves of the three levels do not show the same relative positions over the period. In the case of South Korea, the domestic mutual information has the

Table 3 Triple Helix sectorial outputs for South Korea (2001-2010)

\begin{tabular}{|c|c|c|c|c|c|c|c|c|c|}
\hline & \multicolumn{3}{|l|}{ U } & \multicolumn{3}{|l|}{1} & \multicolumn{3}{|l|}{ G } \\
\hline & $\bar{D}$ & $f$ & G & $\mathrm{D}$ & $\mathrm{F}$ & $\mathrm{g}$ & $\bar{D}$ & $f$ & g \\
\hline 2001 & 12,836 & 2416 & 12,221 & 271 & 32 & 246 & 3107 & 513 & 2740 \\
\hline 2002 & 14,400 & 2946 & 13,628 & 311 & 41 & 260 & 3238 & 606 & 2810 \\
\hline 2003 & 17,685 & 3703 & 16,732 & 334 & 65 & 298 & 3899 & 804 & 3322 \\
\hline 2004 & 19,595 & 3909 & 18,543 & 391 & 68 & 342 & 4108 & 787 & 3502 \\
\hline 2005 & 22,412 & 4534 & 21,207 & 440 & 55 & 380 & 4853 & 901 & 4126 \\
\hline 2006 & 25,114 & 5055 & 23,845 & 478 & 67 & 398 & 5390 & 996 & 4621 \\
\hline 2007 & 30,263 & 5557 & 28,884 & 561 & 68 & 488 & 6591 & 1049 & 5682 \\
\hline 2008 & 30,939 & 6195 & 29,349 & 526 & 46 & 422 & 6023 & 1152 & 5067 \\
\hline 2009 & 33,626 & 6964 & 31,863 & 399 & 86 & 381 & 6186 & 1207 & 5105 \\
\hline 2010 & 34,325 & 7823 & 32,371 & 381 & 67 & 289 & 6478 & 1305 & 5240 \\
\hline Total & 241,195 & 49,102 & 228,643 & 4092 & 595 & 3504 & 49,873 & 9320 & 42,215 \\
\hline
\end{tabular}


Table 4 Triple Helix sectorial outputs for South Korea (2001-2010)

\begin{tabular}{|c|c|c|c|c|c|c|c|c|c|c|c|c|}
\hline & $\underline{\mathrm{UI}}$ & & & UG & & & IG & & & $\underline{U I G}$ & & \\
\hline & $d$ & $\mathrm{~F}$ & g & $\mathrm{D}$ & $\mathrm{F}$ & G & $\mathrm{D}$ & $f$ & g & $d$ & $f$ & g \\
\hline 2001 & 276 & 32 & 334 & 2160 & 497 & 3246 & 72 & 11 & 85 & 57 & 17 & 102 \\
\hline 2002 & 343 & 45 & 432 & 2551 & 599 & 3853 & 71 & 13 & 89 & 87 & 16 & 136 \\
\hline 2003 & 463 & 44 & 547 & 3339 & 711 & 4978 & 78 & 24 & 103 & 106 & 21 & 180 \\
\hline 2004 & 476 & 55 & 597 & 3728 & 842 & 5502 & 100 & 15 & 115 & 129 & 26 & 199 \\
\hline 2005 & 541 & 53 & 654 & 4258 & 1065 & 6369 & 127 & 19 & 141 & 119 & 30 & 197 \\
\hline 2006 & 615 & 79 & 772 & 4752 & 1084 & 6931 & 150 & 16 & 167 & 157 & 35 & 245 \\
\hline 2007 & 742 & 70 & 888 & 5282 & 1300 & 7804 & 113 & 14 & 134 & 192 & 45 & 290 \\
\hline 2008 & 850 & 70 & 998 & 6084 & 1479 & 8852 & 128 & 23 & 145 & 190 & 51 & 313 \\
\hline 2009 & 962 & 89 & 1144 & 6989 & 1716 & 10,062 & 136 & 32 & 157 & 255 & 64 & 392 \\
\hline 2010 & 994 & 86 & 1156 & 7658 & 1969 & 11,106 & 141 & 33 & 157 & 255 & 75 & 409 \\
\hline Total & 6262 & 623 & 7522 & 46,801 & 11,262 & 68,703 & 1116 & 200 & 1293 & 1547 & 380 & 2463 \\
\hline
\end{tabular}

highest (absolute) value and decreased, except in 2009 where it took the median position. The global mutual information is lower (in absolute value) than the domestic one over the period; the foreign mutual information has either the top position or the median one (Fig. 2). In the case of West Africa, however, the relative positions of the curves are no longer identic (Fig. 3). Indeed, the foreign mutual information has the highest (absolute) value except in 2001 and 2006 where it has the lowest. The domestic mutual information has the highest absolute value in 2001 and 2006 and keeps the median position over the rest of the period. The global mutual information gets the lowest absolute value over the period except 2001 and 2006.

In summary, globally, the foreign mutual information is higher (in absolute value) than the domestic one in the case of West Africa, but the South Korean innovation system exhibits an opposite pattern. In other words, the synergy operates more at the foreign level than at the domestic one in the case of West Africa but the reverse is recorded in the case of South Korea. These results suggest that the South Korean domestic system is more integrated than the foreign one and that the West African system is less integrated than the foreign one.

At a country level, innovation actors are submitted to the same rules and policies; they have the same domestic socioeconomic backgrounds and research agendas. On the other side, the foreign actors come from different countries; they are submitted to different policies and research agendas; therefore, the cohesion in their actions could not have the same strength as in the case of national actors. West African institutional partners even coming from different horizons seem more organised than the West Africa-based innovation actors.

The global transmission power is highest in the case of South Korea. The foreign transmission power's relative position has changed over the period: it was the lowest over the period, except in 2004 and 2009, where it was median; it has interchanged its position with the domestic transmission power (Fig. 4). The same global trend was registered in the case of West Africa: the global transmission power is higher than the domestic one but the foreign one changed positions over the period (Fig. 5). The mutual information measures the quantity of information common to the random variables in the system (Shannon 1948). It then measures the quantity of information 
Table 5 Triple Helix sectorial outputs for the West African region (2001-2010)

\begin{tabular}{|c|c|c|c|c|c|c|c|c|c|c|c|c|c|c|c|c|c|c|c|c|c|}
\hline & \multicolumn{3}{|l|}{$\underline{U}$} & \multicolumn{3}{|l|}{1} & \multicolumn{3}{|l|}{ G } & \multicolumn{3}{|l|}{ UI } & \multicolumn{3}{|l|}{ UG } & \multicolumn{3}{|l|}{ IG } & \multicolumn{3}{|c|}{ UIG } \\
\hline & $d$ & $\mathrm{~F}$ & $\mathrm{~g}$ & $\mathrm{D}$ & $\mathrm{f}$ & $\mathrm{g}$ & D & $F$ & $\mathrm{~g}$ & $\mathrm{D}$ & $\mathrm{F}$ & G & D & f & g & $\mathrm{d}$ & f & $\mathrm{g}$ & $d$ & f & g \\
\hline 2001 & 829 & 376 & 819 & 4 & 1 & 4 & 471 & 161 & 321 & 1 & 1 & 2 & 112 & 146 & 387 & 1 & 0 & 2 & 0 & 4 & 4 \\
\hline 2002 & 940 & 395 & 896 & 7 & 5 & 6 & 474 & 189 & 307 & 0 & 3 & 3 & 134 & 185 & 458 & 1 & 0 & 2 & 0 & 2 & 6 \\
\hline 2003 & 1002 & 471 & 971 & 10 & 6 & 6 & 509 & 180 & 310 & 3 & 2 & 8 & 162 & 212 & 526 & 1 & 2 & 4 & 0 & 6 & 10 \\
\hline 2004 & 1149 & 525 & 1112 & 4 & 4 & 2 & 491 & 184 & 297 & 2 & 2 & 9 & 163 & 237 & 562 & 0 & 2 & 2 & 0 & 2 & 3 \\
\hline 2005 & 1525 & 653 & 1450 & 6 & 6 & 4 & 673 & 294 & 421 & 3 & 2 & 8 & 272 & 272 & 774 & 1 & 1 & 3 & 0 & 2 & 5 \\
\hline 2006 & 1594 & 700 & 1547 & 6 & 2 & 4 & 667 & 235 & 393 & 6 & 3 & 11 & 253 & 324 & 763 & 0 & 6 & 4 & 2 & 5 & 11 \\
\hline 2007 & 2198 & 805 & 2058 & 9 & 6 & 9 & 750 & 285 & 439 & 8 & 3 & 12 & 351 & 350 & 964 & 1 & 6 & 6 & 0 & 6 & 12 \\
\hline 2008 & 2632 & 928 & 2497 & 11 & 5 & 7 & 783 & 272 & 437 & 13 & 8 & 25 & 426 & 407 & 1094 & 5 & 3 & 6 & 3 & 14 & 22 \\
\hline 2009 & 3055 & 1056 & 2887 & 10 & 6 & 7 & 788 & 308 & 434 & 12 & 8 & 22 & 468 & 492 & 1234 & 2 & 0 & 2 & 1 & 4 & 11 \\
\hline 2010 & 3053 & 1160 & 2825 & 12 & 10 & 5 & 999 & 377 & 563 & 13 & 5 & 23 & 546 & 587 & 1457 & 2 & 3 & 3 & 2 & 13 & 28 \\
\hline Total & 17,977 & 7069 & 17,062 & 79 & 51 & 54 & 6605 & 2485 & 3922 & 61 & 37 & 123 & 2887 & 3212 & 8219 & 14 & 23 & 34 & 8 & 58 & 112 \\
\hline
\end{tabular}


Table 6 Mutual information ( $T_{\text {uig, }}$ in millibits) and transmission power $(\tau)$ for West Africa (2001-2010) at domestic, foreign and global levels

\begin{tabular}{|c|c|c|c|c|c|c|c|}
\hline \multirow[t]{2}{*}{ Year } & \multicolumn{2}{|c|}{ Domestic } & \multicolumn{2}{|l|}{ Foreign } & \multicolumn{2}{|l|}{ Global } & \multirow{2}{*}{$\frac{\tau_{g}-\tau_{d}}{\tau_{g}}(\%)$} \\
\hline & $T_{\text {uig }}$ & $\tau_{d}$ & $T_{\text {uig }}$ & $\tau_{f}$ & $T_{\text {uig }}$ & $\tau_{g}$ & \\
\hline 2001 & -20.23 & 3.22 & -17.603 & 5.17 & -18.029 & 6.4 & 98.76 \\
\hline 2002 & -29.812 & 4.99 & -39.916 & 12.35 & -23.39 & 9.55 & 91.38 \\
\hline 2003 & -36.401 & 6.37 & -41.408 & 14.26 & -19.288 & 8.76 & 37.52 \\
\hline 2004 & -16.608 & 3 & -23.915 & 8.72 & -6.497 & 3.16 & 5.33 \\
\hline 2005 & -17.413 & 3.38 & -30.6 & 9.09 & -9.648 & 4.62 & 36.69 \\
\hline 2006 & -18.789 & 3.59 & -7.668 & 2.93 & -9.441 & 4.69 & 30.64 \\
\hline 2007 & -18.564 & 3.92 & -22.536 & 7.94 & -14.643 & 7.84 & 100.00 \\
\hline 2008 & -17.86 & 4.11 & -20.783 & 8.53 & -10.203 & 6.14 & 49.39 \\
\hline 2009 & -15.459 & 3.78 & -21.543 & 9.14 & -9.73 & 6.46 & 70.90 \\
\hline 2010 & -17.613 & 4 & -29.975 & 12.55 & -7.818 & 4.86 & 21.50 \\
\hline $2001-2010$ & -19.411 & 3.96 & -24.716 & 9.14 & -11.636 & 6.1 & 54.04 \\
\hline
\end{tabular}

or knowledge shared within the innovation actors. The transmission power is 'the strength of the information flow within the system or between its actors.' (Mêgnigbêto 2014a). Therefore, the knowledge sharing is more efficient in the global system than the domestic one, for both South Korea and West Africa. The global system ensures a better knowledge circulation among innovation actors.

\section{Effect of international collaboration}

The effect of the international collaboration on the knowledge flow is computed in the last columns of Table 6 and Table 7 and displayed in Fig. 6. If South Korea has gained a little with regard to its domestic transmission power (7-24\%, with an average of $12 \%$ over the 10-year period), the involvement in international collaboration has even doubled the West African knowledge circulation capacity. The region has gained from

Table 7 Mutual information ( $T_{\text {uig, }}$ in millibits) and transmission power $(\tau)$ for South Korea (2001-2010) at domestic, foreign and global levels

\begin{tabular}{|c|c|c|c|c|c|c|c|}
\hline \multirow[t]{2}{*}{ Year } & \multicolumn{2}{|c|}{ South Korea } & \multicolumn{2}{|l|}{ Foreign } & \multicolumn{2}{|l|}{ Global } & \multirow[t]{2}{*}{$\frac{\tau_{g}-\tau_{d}}{\tau_{g}}(\%)$} \\
\hline & $T_{\text {uig }}$ & $\tau_{d}$ & $T_{\text {uig }}$ & $\tau_{f}$ & $T_{\text {uig }}$ & $\tau_{g}$ & \\
\hline 2001 & -58.151 & 15.32 & -41.944 & 13.24 & -49.904 & 17.45 & 13.90 \\
\hline 2002 & -59.328 & 16.81 & -42.293 & 13.54 & -46.684 & 18.08 & 7.56 \\
\hline 2003 & -52.915 & 15.77 & -49.976 & 14.71 & -43.775 & 18.04 & 14.39 \\
\hline 2004 & -54.57 & 16.75 & -51.463 & 17 & -44.625 & 18.93 & 13.01 \\
\hline 2005 & -52.934 & 15.86 & -38.124 & 13.43 & -43.132 & 17.97 & 13.30 \\
\hline 2006 & $-51,671$ & 15.61 & $-42,402$ & 14.45 & $-40,816$ & 16,86 & 8.01 \\
\hline 2007 & $-54,291$ & 15.75 & $-41,293$ & 15.13 & $-44,681$ & 17.55 & 11.43 \\
\hline 2008 & $-47,751$ & 15.8 & $-26,366$ & 9.97 & $-36,78$ & 17.07 & 8.04 \\
\hline 2009 & $-35,686$ & 12.84 & $-37,811$ & 15.03 & -31 & 15.85 & 23.44 \\
\hline 2010 & $-33,218$ & 12.19 & $-28,651$ & 11.96 & $-23,898$ & 12.93 & 6.07 \\
\hline 2001-2010 & $-48,036$ & 15.17 & $-38,561$ & 13.89 & $-38,685$ & 17 & 12.06 \\
\hline
\end{tabular}




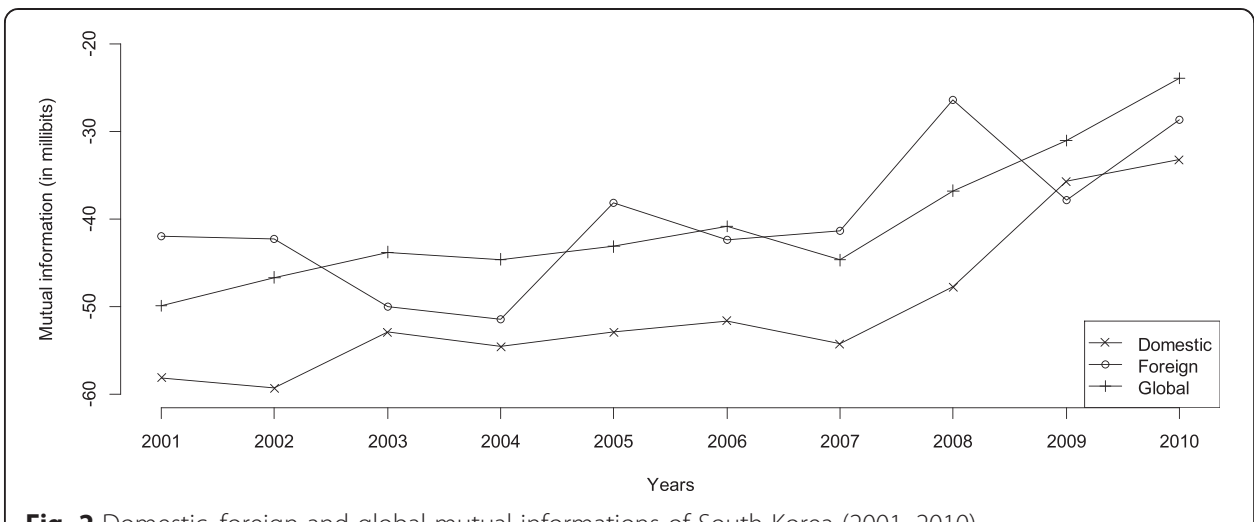

Fig. 2 Domestic, foreign and global mutual informations of South Korea (2001-2010)

5.33 to $100 \%$ of its knowledge-sharing capacity with an average of $54.04 \%$ over the 10 -year period.

\section{Discussion}

West Africa and South Korea display opposite patterns with regard to the relative positions of the foreign and domestic mutual information curves. Indeed, whereas the domestic mutual information is higher in absolute value than the foreign one in the case of South Korea, the reverse is recorded for West Africa. According to Leydesdorff (2003) and Leydesdorff (2008), when the mutual information is negative, it indicates the level of synergy within a system, the extent to which a system is self-organised. This result leads to the conclusion that the West African innovation system is less organised than the set of its institutional partners considered as coming from the same country, and conversely that the South Korean innovation system is more integrated by itself. In fact, South Korea has strengthened its national innovation system after years of benefiting from international collaboration (Mêgnigbêto 2015a; Mêgnigbêto 2015b) following changes in its policies over decades (Kwon et al. 2012). The stead investment in research and development may have strengthened the collaboration between innovation actors at the country level and explains the performance of South Korea (Mêgnigbêto

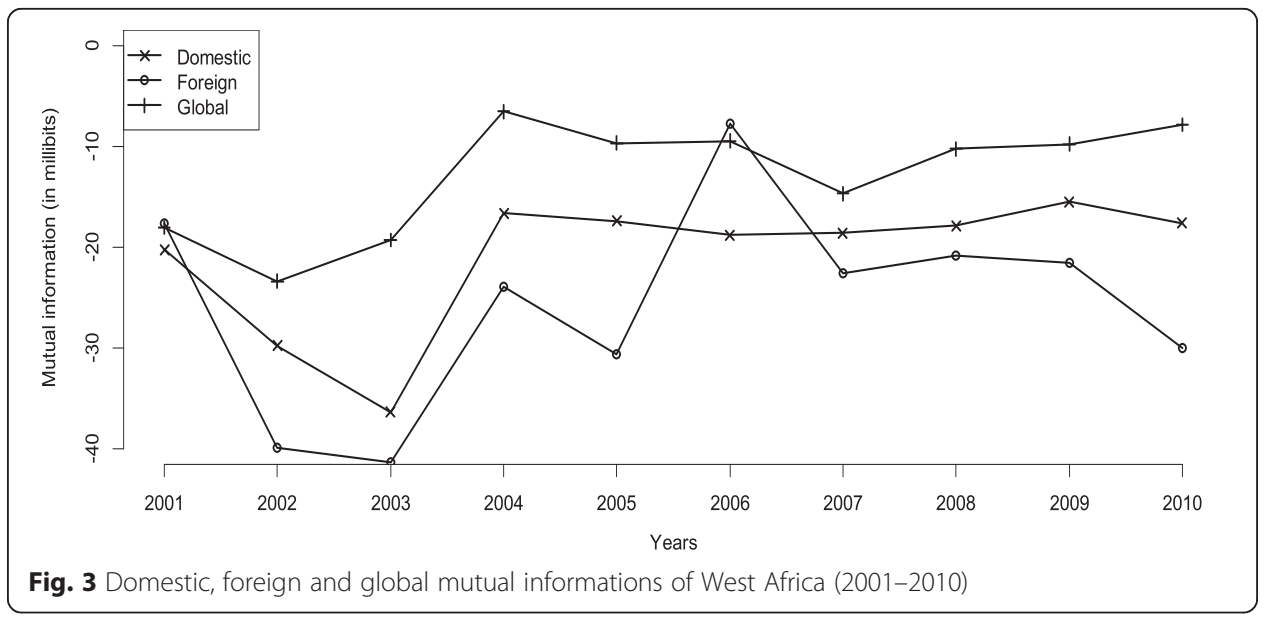




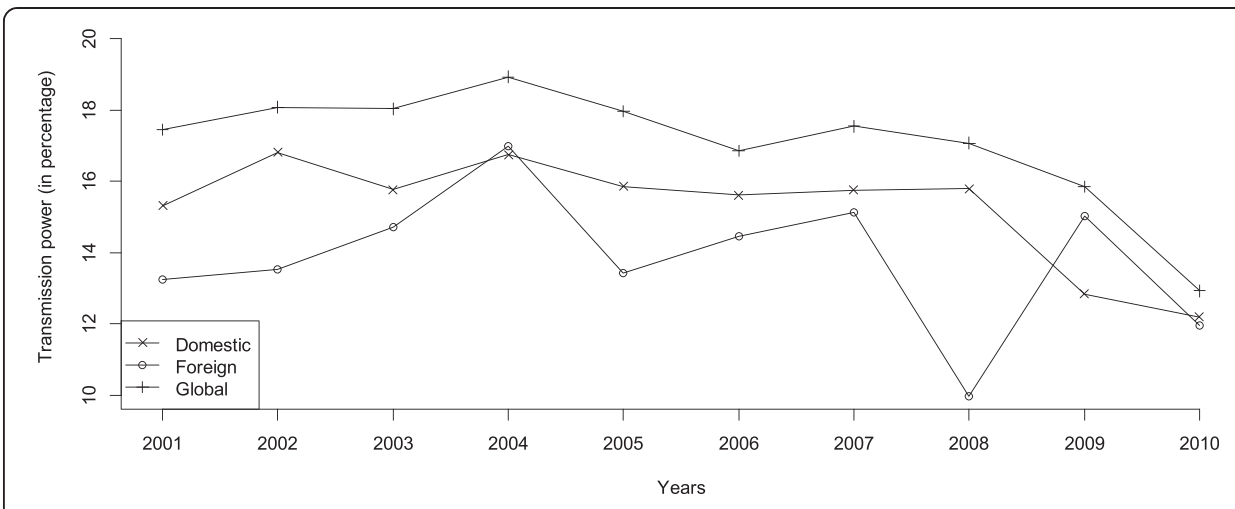

Fig. 4 Domestic, foreign and global transmission power for South Korea (2001-2010)

2015a; Mêgnigbêto 2015b). It illustrates the efforts done by South Korea to catch-up with leading economies (OECD 2009).

West Africa is a 'region' composed of 15 countries. It is also an economic integration area with supranational institutions that have the role to conceive and apply policies at regional level. Even though the ECOWAS has formulated sectorial policies (e.g. agriculture and industry), it is recently, in 2012, that the Economic Community of West African States Policy on Science and Technology (ECOPOST) was adopted. Actually, it is hard to know the actions executed and the progress achieved toward a regional innovation system. Furthermore, not all ECOWAS member states have a science and technology policy (Oti-Boateng 2010). ${ }^{10}$ Globally, the West African national innovation system is hindered by many factors among which are the following: (1) the instability of the institutional framework, (2) the inadequate coordination within the system, (3) the lack of coordination between research programmes and research activities, (4) the lack of optimal use of human resources and loss of motivation of researchers, (5) the lack of human and financial resources and equipment, (6) the weaknesses in the institutional framework, (7) the lack or weaknesses in the actors network, (8) the weak improvement of research status and (9) the insufficiencies or inadequacies of funding and equipment (cf. (African Union et al. 2011; Mêgnigbêto 2013c). Consequently, research in this part of the word is driven by foreign actors and not by national or regional agendas. Even the

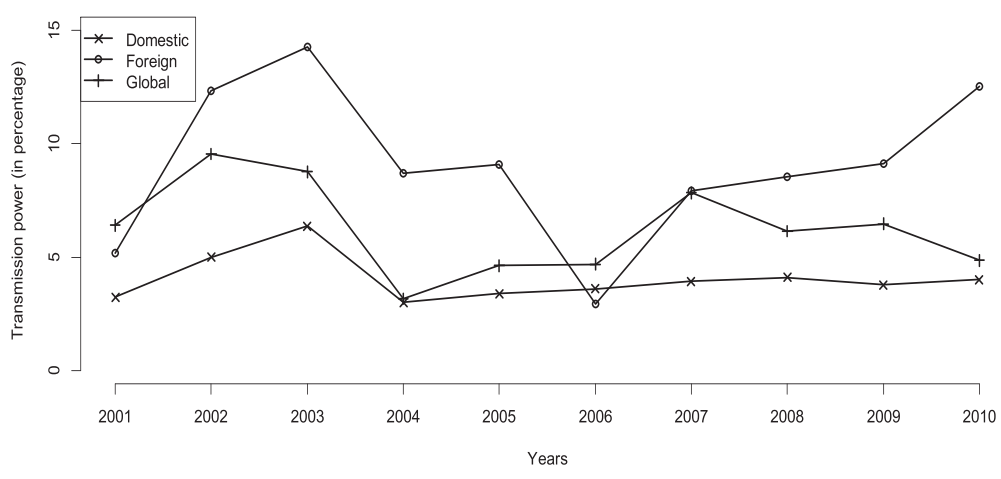

Fig. 5 Domestic, foreign and global transmission power for West Africa (2001-2010) 


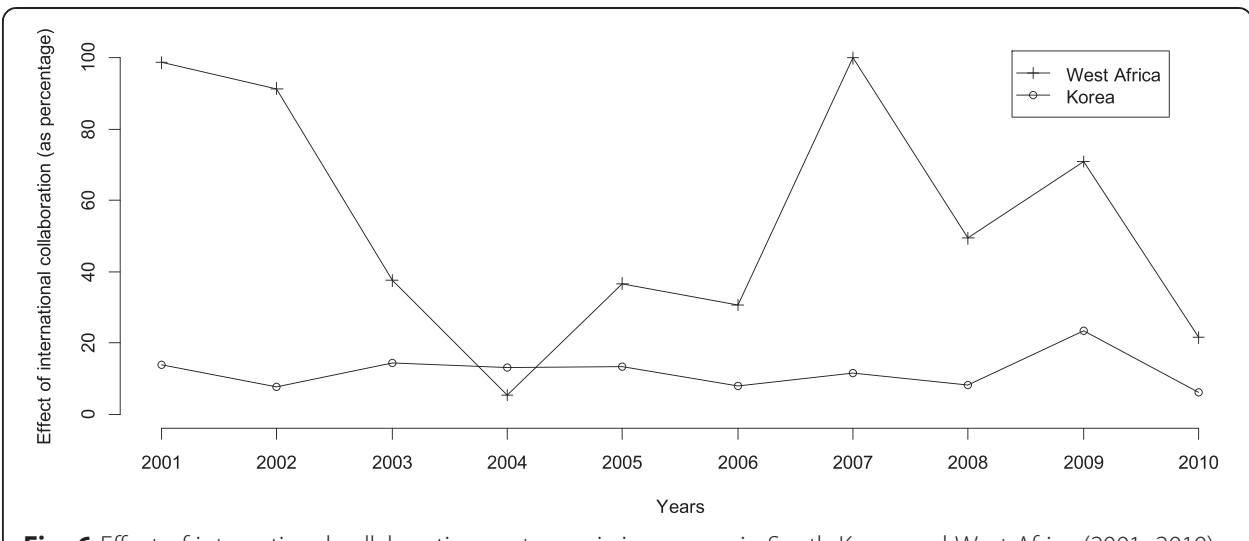

Fig. 6 Effect of international collaboration on transmission power in South Korea and West Africa (2001-2010)

intraregional collaboration is driven by international organisations or institutions with national representations in countries of West Africa (Mêgnigbêto 2013c). That explains the high rate of international collaboration in the West African science (about $50 \%$ against $21 \%$ for South Korea); that also explains why the West African domestic mutual information is weaker (in absolute value) than the foreign one.

In our opinion, the relative positions of the South Korean mutual information at the foreign and domestic levels seem to be the normal one. Indeed, a national system should be more integrated than a set of institutions from different horizons (named here foreign) because the components of the former are ruled by the same policies and have the same research agendas. This normal situation was also registered by (Shin et al. 2012) for Saudi Arabia.

West Africa does not appear like a single unit of analysis; indeed, member countries do not exhibit the same pattern. Some are more integrated and others less than their partners. In other words, some countries are affected positively by international collaboration (e.g. Burkina Faso, Ghana and Nigeria) and others negatively (e.g. The Gambia, Cape Verde, Cote d'Ivoire). However, the size of the sample we considered may have affected the West African results at both regional and national levels. Therefore, the resulting analysis could not be confident. The large variability of the effect of international collaboration on knowledge sharing in West Africa (cf. Fig. 6) is an illustration.

The main result of this research is that the international collaboration the two areas under study are involved in affected the synergy at their domestic level and also how knowledge is created and flows between innovation actors. In the case of South Korea, international collaboration makes that the country gained about $20 \%$ of its domestic strength of information flow. In case of the West Africa, the effect goes up to $100 \%$. The relative positions of the mutual informations and the transmission powers in the two areas indicate that the West African innovation system is less integrated than the set of its international partners.

\section{Conclusion}

The objective of this paper was to measure the effect of international collaboration on the mutual information and how knowledge flows among innovations actors. We formulated two research questions. (1) How is the synergy or knowledge contributed to abroad by an area's innovation actors due to their relations with their foreign partners 
measured? (2) What is the effect of international collaboration on knowledge flow within an innovation system? To answer these questions, we distinguished three levels of analysis: the domestic one grouping innovation actors based in the country under study, the foreign level grouping institutional partners and the global one merging the innovations actors from both domestic and foreign levels. We computed the mutual information and the transmission power for South Korea and West Africa for the three levels, and then, we could derive the effect of international collaboration. We found that the foreign mutual information is globally higher (in absolute value) than the domestic one in the case of West Africa, and lower in the case of South Korea meaning that the South Korean innovation system is integrated by itself, whereas the West African is less integrated than its foreign system. We also found that in the two areas, the global transmission power is higher than the domestic one meaning that international collaboration has strengthened knowledge sharing at the domestic level; in other words, the two areas have benefited from international collaboration in terms of knowledge flow.

\section{Endnotes}

${ }^{1}$ If the number of variables is $n$, the system may be decomposed into $2^{n}$ subsets (Cf. Mêgnigbêto 2014a, pp. 285-286).

${ }^{2}$ The West African region member states are, in alphabetic order: Benin, Burkina Faso, Cape Verde, Cote d'Ivoire, The Gambia, Ghana, Guinea, Guinea-Bissau, Liberia, Mali, Nigeria, Niger, Senegal, Sierra Leone and Togo.

${ }^{3}$ The search expression was ( $c u=$ benin or $c u=B u r k i n a$ faso or $c u=$ cote ivoire or $c u=c a p e$ verde or cu=gambia or cu=ghana or cu=guinea or cu=guinea bissau or cu=liberia or $c u=$ mali or cu=niger or cu=nigeria or cu=senegal or cu=sierra leone or cu=togo) and $(p y=2001-2010)$. It also selected data of countries like Equatorial Guinea and Papua New Guinea due to the term guinea. The records of these two countries that did not result from collaboration with any West African countries were deleted from our local database.

${ }^{4}$ The search expression was $c u=s o u t h$ korea and $p y=2001-2010$.

${ }^{5}$ The databases searched were Science Citation Index Expanded (SCI-EXPANDED), Social Sciences Citation Index (SSCI), Arts \& Humanities Citation Index (A\&HCI), Conference Proceedings Citation Index-Science (CPCI-S) and Conference Proceedings Citation Index-Social Science \& Humanities (CPCI-SSH).

${ }^{6}$ The two databases have the same structure.

${ }^{7} \mathrm{CDS} / \mathrm{ISIS}$ is a text database management software application developed and distributed by UNESCO (UNESCO 1989a) (http://www.unesco.org/isis) and mainly used for bibliographic management (de Smet 2008; de Smet and Dhamdhere 2010).

${ }^{8} \mathrm{CDS} /$ ISIS provides a programming language 'designed to develop CDS/ISIS applications requiring functions which are not readily available in the standard package' (UNESCO 1989b). This programming language enables users to extend functions of the standard package, to make it more robust and in order to meet users' specific needs (Mêgnigbêto 1998).

${ }^{9}$ Not categorised addresses were labelled ' $\mathrm{NC}$ '; so the inverted file also contained NC-WEST AFRICA, NC-FOREIGN for the West African database and NC-KOREA, NC-FOREIGN for the Korean database.

${ }^{10}$ UNESCO distinguished eight ECOWAS member states in three groups: those who have national STI policy (1), incomplete/nonfunctional out dated STI policies per sector (2) and, those without any STI policy (5) (Oti-Boateng 2010). 
${ }^{11}$ In these formulae, the square brackets symbolises the number of records resulting from the search.

${ }^{12}$ For South Korea for example, we conducted the following searches: (1) at domestic level: univ-korea, indu-korea, gov-korea and their bi and trilateral combinations; (2) at foreign level: univ-foreign, indu-foreign, gov-foreign and their bi or trilateral combinations; (3) at global level: univ-korea + univ-foreign, indu-korea + indu-foreign, gov-korea + gov-foreign and their bi and trilateral combinations.

\section{Appendix 1}

Mutual information and transmission power

Shannon (1948) defined the entropy of an event that occurs with the probability $p$ as

$$
H=-p \times \log _{2} p-(1-p) \times \log _{2}(1-p)
$$

where $\log _{2}$ is the logarithm to the base 2; the entropy may, however, be computed to other bases, e.g. $3,4, \ldots, 10)$. More generally, if $X=\left(x_{1}, x_{2}, \ldots, x_{\mathrm{n}}\right)$ is a random variable and its components occur with the probabilities $p_{1}, p_{2}, \ldots, p_{\mathrm{n}}$, respectively, then the entropy generated by $X$ is (Shannon 1948; Shannon and Weaver 1949)

$$
H_{\mathrm{X}}=-\sum_{i=1}^{n} p_{\mathrm{i}} \times \log _{2} p_{\mathrm{i}}
$$

For two random variables $X$ and $Y$, if $H_{\mathrm{X}}$ is the entropy of $X$ and $H_{\mathrm{Y}}$ that of $Y$, the joint entropy $H_{\mathrm{XY}}$ of the system of the two variables is equal to the entropy $H_{\mathrm{X}}$ plus $H_{\mathrm{Y}}$ minus the entropy of the overlay of $X$ and $Y$. The latter is called 'rate of transmission' (Shannon 1948) or mutual information (Yeung 2001; Leydesdorff 2003; Cover and Thomas 2006; Mori 2006; Leydesdorff 2008; Yeung 2008) between $X$ and $Y$. The relations between the transmission, $T_{\mathrm{XY}}$, the joint entropy $H_{\mathrm{XY}}$ and the marginal entropies of the variables, $H_{\mathrm{X}}$ and $H_{\mathrm{Y}}$, are (Shannon 1948)

$$
H_{\mathrm{XY}}=H_{\mathrm{X}}+H_{\mathrm{Y}}-T_{\mathrm{XY}}
$$

and

$$
T_{\mathrm{XY}}=H_{\mathrm{X}}+H_{\mathrm{Y}}-H_{\mathrm{XY}}
$$

In case of three random variables $X, Y$ and $Z$ (three dimensions), the relations between the system's entropy, its transmission, the marginal entropies and the bilateral transmissions are given by (cf. (Abramson 1963; Theil 1972; Leydesdorff 2003):

$$
H_{\mathrm{XYZ}}=H_{\mathrm{X}}+H_{\mathrm{Y}}+H_{\mathrm{Z}}-T_{\mathrm{XY}}-T_{\mathrm{XZ}}-T_{\mathrm{YZ}}+T_{\mathrm{XYZ}}
$$

and

$$
T_{\mathrm{XYZ}}=H_{\mathrm{X}}+H_{\mathrm{Y}}+H_{\mathrm{Z}}-H_{\mathrm{XY}}-H_{\mathrm{YZ}}-H_{\mathrm{XZ}}+H_{\mathrm{XYZ}}
$$

The transmission power of a system is the fraction of the maximum value of the transmission devoted to information sharing in the system; it represents the share of the 'total configurational information' really produced in the system. In other words, it measures the efficiency of the mutual information. 
For a three-dimensional system, Mêgnigbêto (2014a) distinguished two types of transmission power: the first one $\left(\tau_{1}\right)$ when the transmission is negative and the second $\left(\tau_{2}\right)$ when the transmission is positive:

$$
\tau=\left\{\begin{aligned}
\tau_{1}=\frac{T_{\mathrm{XYZ}}}{H_{\mathrm{XYZ}}-H_{\mathrm{X}}-H_{\mathrm{Y}}-H_{\mathrm{Z}}} & \text { if } \mid T_{\mathrm{XYZ}}<0 \\
\tau_{2}=\frac{T_{\mathrm{XYZ}}}{H_{\mathrm{XYZ}}} & \text { if } \mid T_{\mathrm{XYZ}}>0 \\
0 & \text { if } \mid T_{\mathrm{XYZ}}=0
\end{aligned}\right.
$$

The transmission power varies from 0 to 1 ; it is dimensionless and may be expressed as percentage (Mêgnigbêto 2014a).

\section{Appendix 2}

\section{Search strategy within the local database}

The CDS/ISIS search function operates mainly over the inverted file that contains 'searchable terms' as initially defined by the database administrator into a file called Field Selection Table (UNESCO 1989a). It admits the Boolean operators OR symbolised by the sign + (plus), AND symbolised by the character * (star) and NOT symbolised by the character ${ }^{\wedge}$ (circumflex). It also admits free search expression and parentheses to prioritise part of a search expression (UNESCO 1989a) and hashtag (\#) to recall a previous search by its number. The following searches summarise the search strategy adopted (the example is based on the South Korean case):

\#1: UNIV-SOUTH KOREA selects all records with at least one South Korean-based university in affiliation;

\#2: INDU-SOUTH KOREA selects all records with at least one South Korean-based industry in affiliation;

\#3: GOV-SOUTH KOREA selects all records with at least one South Korean-based government in affiliation;

\#4: \#1* \#2 selects all records with at least one South Korean-based university AND one South Korean-based industry in affiliation;

\#5: \#1 * \#3 selects all records with at least one South Korean-based university AND one South Korean-based government in affiliation;

\#6: \#2* \#3 selects all records with at least one South Korean-based industry AND one South Korean-based government in affiliation;

\#7: \#1*\#2*\#3 selects all records with at least one South Korean-based university AND one South Korean-based industry AND one South Korean-based government in affiliation.

The results of each stage were entered into a worksheet, and on a second worksheet, formulas were entered to compute university, industry and government sectorial output and other bilateral and trilateral collaboration data using the formulas, ${ }^{11}$ following the logical relations between sets in (1) $U=[1]-[4]-[5]+[7]$, (2) $I=[2]-[4]-[6]+[7]$, (3) $\mathrm{G}=[3]-[5]-[6]+[7],(4) \mathrm{UI}=[4]-[7],(5) \mathrm{UG}=[5]-[7],(6) \mathrm{IG}=[6]-[7]$ and (7) $\mathrm{UIG}=[7]$. 
This strategy was executed for each area at the three levels (domestic, foreign and global). ${ }^{12}$

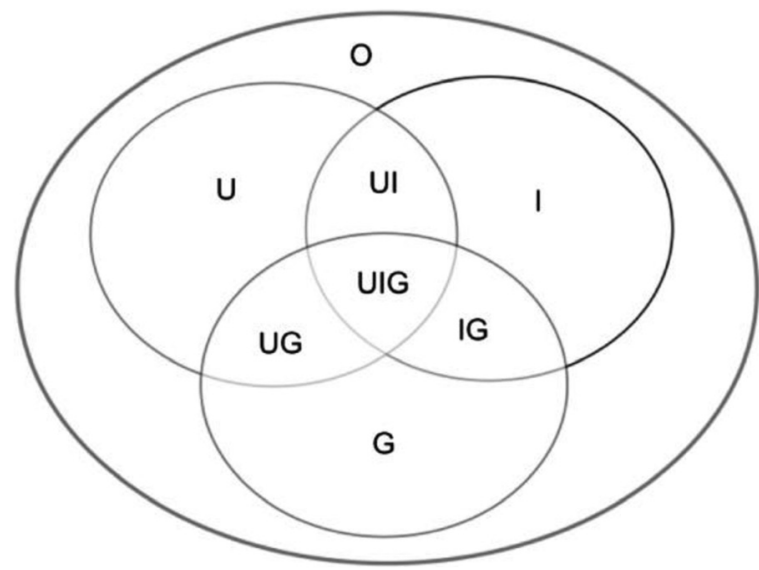

Fig. 7 Cardinalities in a tri-dimensional system $S=(U, I, G)$

\section{Additional file}

Additional file 1: Translation of the abstract into Arabic.

Received: 30 June 2015 Accepted: 20 October 2015

Published online: 02 November 2015

\section{References}

Abbassi A, Liaquat $H$, Leydesdorff $L$ (2012) Betweeness centrality as a driver of preferential attachment in the evolution of research collaboration networks. J Informetr 6:403-412

Abramson N (1963) Information theory and coding. McGraw-Hill, New York, etc

Adams J (2012) Collaborations: the rise of research networks. Nature 490:335-336. doi:10.1038/490335a

Adams J (2013) The fourth age of research. Nature 497:557-560. doi:10.1038/490335a

Adams J, Gurney K, Hook D, Leydesdorff L (2014) International collaboration clusters in Africa. Scientometrics 98:547-556. doi:10.1007/s11192-013-1060-2

Adams J, King C, Hook D (2010a) Global research report: Africa. Thomson Reuters

Adams J, King C, Miyairi N, Pendlebury D (2010b) Global research report: Japan. Thomson Reuters, Philadelphia

African Union, Economic Community of the West African States, United Nations Economic Commission for Africa,

United Nations, Educational, Scientific and Cultural Organisation (2011) Making science and technology information more accessible for Africa's development. Abuja, Nigeria, 17-18 October 2011

Bordons M, Gomez I (2000) Collaboration networks in science. In: Cronin B, Atkins HB (eds) A festschrift in honor of Eugene Garfield. Information Today, Medford, pp 197-213

Boshoff N (2009) Neo-colonialism and research collaboration in Central Africa. Scientometrics 81:413-434

Choi S, Yang JS, Park HW (2015) The triple helix and international collaboration in science. J Assoc Inf Sci Technol $66: 201-212$

Cover TM, Thomas JA (2006) Elements of information theory, 2nd edn. J. Wiley, Hoboken

de Smet E (2008) The ISIS-software family: from "Free and Open" to 'free and open source software. Innov J Appropr Librariansh Inf Work 36:38-47

de Smet E, Dhamdhere S (2010) ABCD: an open source automation tool for libraries. Pearl J Libr Inf Sci 4:215-219

Etzkowitz H, Leydesdorff L (1995) The Triple Helix - university-industry-government relations: a laboratory for knowledge-based economic development. EEASST Rev 14:14-19

Etzkowitz H, Leydesdorff L (2000) The dynamics of innovation: from national systems and "Mode 2"' to a Triple Helix of university-industry-government relations. Res Policy 29:109-123

Godin B (2005) The linear model of innovation: the historical construction of an analytical framework. Institut National de la Recherche Scientifique. Montréal, Québec, Canada

Godin B (2006) The linear model of innovation: the historical construction of an analytical framework. Sci Technol Hum Values 31:639-667

Godin B (2014) Invention, diffusion and linear models of innovation: the contribution of anthropology to a conceptual framework. J Innov Econ Manag 3:11-37. doi:10.3917/jie.015.0011

Godin B (2007) National innovation system: the system approach in historical perspective. Institut National de la Recherche Scientifique. Montréal, Québec, Canada

Guns R, Rousseau R (2014) Recommending research collaborations using link prediction and random forest classifiers. Scientometrics 101:1461-1473. doi:10.1007/s11192-013-1228-9 
Ivanova IA, Strand $\varnothing$, Leydesdorff $L$ (2014) Synergy cycles in the Norwegian innovation system: the relation between synergy and cycle values

Katz JS, Martin BR (1997) What is research collaboration? Res Policy 26:1-26

Khan FG, Park HW (2011) Measuring the Triple Helix on the Web: longitudinal trends in the university-industry-government relationship in Korea. J Am Soc Inf Sci 62:2443-2455

Kwon K-S (2011) The co-evolution of universities' academic research and knowledge-transfer activities: the case of South Korea. Sci Public Policy 38:493-503

Kwon K-S, Park HW, So M, Leydesdorff L (2012) Has globalization strengthened South Korea's national research system? National and international dynamics of the Triple Helix of scientific co-authorship relationships in South Korea. Scientometrics 90:163-176

Leydesdorff L (2012) The Triple Helix, Quadruple Helix, ..., an N-tuple of Helices: explanatory models for analyzing the knowledge-based economy? J Knowl Econ 3:25-35

Leydesdorff L (2003) The mutual information of university-industry-government relations: an indicator of the Triple Helix dynamics. Scientometrics 58:445-467

Leydesdorff L (2008) Configurational information as potentially negative entropy: the Triple Helix model. Entropy 10:391-410. doi:10.3390/e10040391

Leydesdorff $L$, Etzkowitz $\mathrm{H}$ (2001) The transformation of university-industry-government relations

Leydesdorff L, Park H (2014) Can synergy in Triple Helix relations be quantified? A review of the development of the Triple Helix indicator. Triple Helix J Univ-Ind-Gov Innov Entrep 1:1-18. doi:10.1186/s40604-014-0004-z

Leydesdorff L, Park HW, Lengyelc B (2013a) A routine for measuring synergy in university-industry-government relations: mutual information as a Triple-Helix and Quadruple-Helix indicator. Scientometrics 99:7-35. doi:10.1007/s11192-013-1079-4

Leydesdorff L, Perevodchikov E, Uvarov A (2015) Measuring triple-helix synergy in the Russian innovation systems at regional, provincial, and national levels. J Assoc Inf Sci Technol 66:1229-1238. doi:10.1002/asi.23258

Leydesdorff L, Sun Y (2009) National and international dimensions of the Triple Helix in Japan: university-industry-government versus international co-authorship relations. J Am Soc Inf Sci 60:778-788

Leydesdorff L, Wagner C, Park H-W, Adams J (2013b) International collaboration in science: the global map and the network. El Prof Inf 22:87-94, doi:http://dx.doi.org/10.3145/epi.2013.ene.12

Leydesdorff L, Wagner CS (2008) International collaboration in science and the formation of a core group. J Informetr 2:317-325

Leydesdorff L, Zawdie G (2010) The Triple Helix perspective of innovation systems. Technol Anal Strateg Manag 22:789-804

Leydesdorff L, Zhou P (2013) Measuring the knowledge-based economy of China in terms of synergy among technological, organizational, and geographic attributes of firms. Scientometrics 98:1703-1719

Mêgnigbêto E (2013a) Triple Helix of university-industry-government relationships in West Africa. J Scientometr Res 2:54-62. doi:10.4103/2320-0057.135413

Mêgnigbêto E (2015a) Correlation between transmission power and some indicators used to measure the knowledge-based economy: case of six OECD countries

Mêgnigbêto E (2015b) Profiles of six OECD countries with regard to mutual information and transmission power. ISSI Newsl 11:16-23

Mêgnigbêto E (2014a) Efficiency, unused capacity and transmission power as indicators of the Triple Helix of universityindustry-government relationships. J Informetr 8:284-294. doi:10.1016/j.joi.2013.12.009

Mêgnigbêto E (2014b) Information flow between West African Triple Helix actors. ISSI Newsl 10:14-20

Mêgnigbêto E (2014c) Information flow within West African innovation systems. Triple Helix J Univ Ind Gov Innov Entrep 1:1-13. doi:10.1186/s40604-014-0005-y

Mêgnigbêto E (2013b) International collaboration in scientific publishing: the case of West Africa (2001-2010). Scientometrics 96:761-783. doi:10.1007/s11192-013-0963-2

Mêgnigbêto E (2013c) Scientific publishing in West Africa: comparing Benin with Ghana and Senegal. Scientometrics 95:1113-1139. doi:10.1007/s11192-012-0948-6

Mêgnigbêto E (1998) Le traitement des particules nobiliaires: une expérience avec CDS/ISIS. Doc-Sci L'information 35:321-325

Meyer M, Grant K, Morlacchi P, Weckowska D (2014) Triple Helix indicators as an emergent area of enquiry: a bibliometric perspective. Scientometrics 99:151-174. doi:10.1007/s11192-013-1103-8

Mori Y (2006) Electronique pour le traitement du signal. Théorie de l'information et du codage: signal analogique, signal numérique et applications en télécommunications. Lavoisier, Paris

OECD (1997) National innovation systems. OECD, Paris

OECD (2009) OECD reviews of innovation policy: Korea. OECD Publishing, Paris

Olmeda-Gómez C, Perianes-Rodríguez A, Antonia Ovalle-Perandones MA (2008) Comparative analysis of universitygovernment-enterprise co-authorship networks in three scientific domains in the region of Madrid

Onyancha OB, Maluleka JR (2011) Knowledge production through collaborative research in sub-Saharan Africa: how much do countries contribute to each other's knowledge output and citation impact? Scientometrics 87:315-336

Ossenblok TLB, Verleysen FT, Engels TCE (2014) Coauthorship of journal articles and book chapters in the social sciences and humanities (2000-2010). J Assoc Inf Sci Technol 65:882-897. doi:10.1002/asi.23015

Oti-Boateng P (2010) Mission report Accra, Ghana, 27th September-1st October, 2010. UNESCO, Nairobi

Park HW, Hong HD, Leydesdorff L (2005) A comparison of the knowledge-based innovation systems in the economies of South Korea and the Netherlands using Triple Helix indicators. Scientometrics 65:3-27

Park HW, Leydesdorff L (2010) Longitudinal trends in networks of university-industry-government relations in South Korea: the role of programmatic incentives. Res Policy 2009:640-649

Development Core Team R (2014) R: a language and environment for statistical computing. R Foundation for Statistical Computing, Vienna

Shannon CE (1948) A mathematical theory of communication. Bell Syst Tech J 27:379-423, and 623-656

Shannon CE, Weaver W (1949) The mathematical theory of communication. University of Illinois, Urbana 
Shin JC, Lee SJ, Kim Y (2012) Knowledge-based innovation and collaboration: a triple-helix approach in Saudi Arabia. Scientometrics 90:311-326. doi:10.1007/s11192-011-0518-3

Theil H (1972) Statistical decomposition analysis: with applications in the social and administrative sciences. North-Holland Publishing Company, Amsterdam/NewYork

Tijssen RJW (2007) Africa's contribution to the worldwide research literature: new analytical perspectives, trends and performance indicators. Scientometrics 71:303-327

Toivanen H, Ponomariov B (2011) African regional innovations systems: bibliometric analysis of research collaboration patterns 2005-2009. Scientometrics 88:471-493

UNESCO (1989a) Mini-micro CDS/ISIS: manuel de référence: version 2.3. UNESCO, Paris

UNESCO (1989b) Mini-micro CDS/ISIS: Pascal CDS/ISIS. UNESCO, Paris

Yeung RW (2001) A first course in information theory. Kluwer Academic Publishers, Boston

Yeung RW (2008) Information theory and network coding. Springer, New York

Ye YF, Yu SS, Leydesdorff L (2013) The Triple Helix of university-industry-government relations at the country level, and its dynamic evolution under the pressures of globalization. J Am Soc Inf Sci Technol 64:2317-2325

Submit your manuscript to a SpringerOpen ${ }^{\circ}$ journal and benefit from:

- Convenient online submission

Rigorous peer review

- Immediate publication on acceptance

- Open access: articles freely available online

- High visibility within the field

Retaining the copyright to your article

Submit your next manuscript at $\gg$ springeropen.com 